M Nanajerial $\quad$ ISSN $\quad: 1412-6613$

\title{
LINGKUNGAN KERJA, MUNGKINKAH TIDAK BERPENGARUH TERHADAP KEPUASAN KERJA?
}

\author{
M Sandi Marta ${ }^{1}$, Budi $^{2}$ \\ Email: sandimarta@uinsgd.ac.id ; budi1148020049@gmail.com
}

\begin{abstract}
ABSTRAK
Terlepas dari fakta banyak karyawan dalam dunia industri modern bekerja dalam pengaturan kantor, para peneliti perilaku organisasi hingga saat ini telah lambat untuk mengenali betapa pentingnya untuk mempelajari efek dari lingkungan kerja pada pekerja kantor. Akibatnya, kita belum membentuk pemahaman yang jelas tentang hubungan antara lingkungan tempat kerja dan perilaku dan hasil kerja pekerja kantor. Dalam esai ini, kami berusaha untuk membuka beberapa masalah yang luas tentang lingkungan kerja fisik dan non fisik yang, pada gilirannya, membentuk perilaku dan sikap pekerja kantor.
\end{abstract}

Kata kunci: Lingkungan Kerja, Lingkungan Kerja Fisik, Lingkungan Kerja Non Fisik, Kepuasan Kerja

\begin{abstract}
Despite the fact that so many employees in the modern industrialized world work in office settings, organizational behavior researchers to date have been slow to recognize how important it is to study the effects of the work environment on office workers. Consequently, we have yet to form a clear understanding of the connection between the workplace environment and office workers' behaviors and outcomes. In this essay, we seek to open some of the broad issues about physical and non physical environment, that, in turn, shape office workers' behaviors and attitudes.
\end{abstract}

Keyword: work environment, physical environment, non physical environment and job satisfaction

\section{PENDAHULUAN}

Organisasi adalah sistem yang tersusun dari berbagai sub sistem yang berfungsi dalam sebuah lingkungan. Salah satu yang terpenting dalam organisasi adalah manajemen. Subsistem manajemen haruslah berusaha menyelaraskan semua sub sistem yang ada sehingga semuanya harmonis satu sama lain, selaras dengan lingkungan organisasi, dan dengan cita-cita atau tujuan sehingga dapat menjadi organisasi yang berkualitas. Banyak sekali faktor yang mempengaruhi keberhasilan suatu perusahaan atau organisasi salah satunya adalah karyawan, karena berkaitan langsung dengan kegiatan organisasi (Utami, 2010). Dalam hal ini karyawan diharapkan dapat memberikan hasil yang maksimal sehingga tujuan dari perusahaan atau organisasi dapat tercapai. Karyawan merupakan komponen penting dalam proses pencapaian misi dan visi bisnis. Pencapaian tersebut dapat direalisasikan jika organisasi menentukan kualitas kerja mereka (Raziq, 2014). Hal itu semua, karena sumberdaya manusia mempunyai peranan penting untuk mewujudkan citacita organisasi (Hasibuan, 2003). Bila karyawan memiliki produktivitas dan motivasi kerja yang tinggi, maka laju organisasipun akan berjalan mulus, yang akhirnya akan menghasilkan kinerja dan pencapaian yang baik bagi organisasi (Hendri, 2012). 
Kepuasan kerja telah menjadi tiang dalam peningkatan kinerja karyawan dapat mencapai tujuan organisasi (Agbozo, 2017). Jika karyawan yang bekerja dalam kondisi lingkungan kerja yang sulit, dapat membuat ketidakpuasan tercipta dalam diri karyawan. Untuk memperbaiki itu semua, perlu manajemen yang efektif untuk memperbaiki lingkungan kerja (Bakotic \& Babic, 2013). Begitu juga dengan organisasi akan kesulitan dalam mencapai tujuannya apabila kondisi dari lingkungan sekitar kurang memadai sehingga kepuasan kerja di organisasi tersebut mengalami penurunan (Dawal dan Taha, 2006). Untuk mencapai standar organisasi yang efektif sehingga kepuasan tercipta, seseorang membutuhkan lingkungan kerja yang mengizinkan mereka untuk bekerja dengan bebas tanpa adanya masalah yang menggangu kemampuan mereka (Raziq, 2014). Salah satunya dengan kebebasan interaksi manusia dengan manusia dapat berperan sangat dominan pada kepuasan kerja karyawan dari pada hanya sekedar uang (Chandrasekar, 2011).

\section{LITERATUR}

\section{Pengaruh Lingkungan Kerja Fisik Terhadap Kepuasan Kerja}

Lingkungan kerja dititikberatkan pada lingkungan kerja fisik. Lingkungan kerja fisik adalah semua keadaan berbentuk fisik yang terdapat di sekitar tempat kerja yang dapat mempengaruhi karyawan baik secara langsung maupun tidak langsung (Sedarmayanti, 2011). Setiap orang pasti membutuhkan rasa nyaman dalam bekerja, apalagi kenyamanan dalam lingkungan kerja fisik yang memang akan bersentuhan langsung dengan tubuh dan dirasakan olah panca indra. Lingkungan kerja fisik sangat erat hubungannya dengan kenyamanan bekerja, sehingga lingkungan kerja fisik yang baik maka akan menimbulkan kenyamanan dan kepusan karyawan dalam bekerja. Misalnya, seseorang atau karyawan akan merasa nyaman dalam bekerja karena lingkungan kerja fisiknya tertata rapi dan bersih, warna-warna cat dinding atau peralatan lainnya serasi dengan apa yang harus dikerjakan, dan penerangan kantor yang memadai. Sarah dan Utami (2016) dalam penelitiannya menyatakan bahwa lingkungan kerja fisik merupakah salah satu factor yang dapat meningkatkan kepuasan kerja.

H1: Terdapat pengaruh positif lingkungan kerja fisik terhadap kepuasan kerja karyawan.

\section{Pengaruh Lingkungan Kerja Non Fisik Terhadap Kepuasan Kerja}

Lingkungan kerja non fisik merupakan lingkungan kerja yang tidak dapat terdeteksi oleh panca indera manusia, namun dapat dirasakan (Dharmawan, 2011). Pendapat tersebut menyatakan bahwa lingkungan kerja non fisik adalah lingkungan kerja yang tidak dapat ditangkap dengan panca indera manusia. Akan tetapi, lingkungan kerja non fisik ini dapat dirasakan oleh para karyawan melalui hubungan-hubungan sesama karyawan maupun dengan atasan. Pengaruh lingkungan kerja non fisik yang baik akan menuntut karyawan mempunyai disiplin kerja yang tinggi dan otomatis akan terjalin kerja sama yang baik dalam perusahaan sehingga akan berpengaruh pada kepuasan kerja karyawan. Tetapi, apabila lingkungan kerja non fisik yang ada di sekeliling karyawan buruk maka akan menyebabkan rendahnya disiplin kerja sehingga kepuasan kerja akan menurun. Dengan menciptakan lingkungan kerja non fisik yang nyaman, dimana hubungan antar rekan kerja yang harmonis akan mampu memicu terjalinnya kerja sama kerja karyawan yg baik dalam melaksanakan tugas-tugasnya. Makin harmonis hubungan kerja karyawan, makin besar pula peluangnya untuk mencari hal-hal baru yang dapat lebih meringankan pekerjaan. Fath (2015) dalam penelitiannya menyatakan bahwa lingkungan kerja non fisik memiliki andil dalam mencapai kepuasan kerja karyawan di hotel bintang dua di Yogyakarta. 


\begin{tabular}{|lll}
\hline$M$ & ISSN & $: 1412-6613$ \\
& E-ISSN & $: 2527-4570$
\end{tabular}

H2: Terdapat pengaruh positif lingkungan kerja non fisik terhadap kepuasan kerja karyawan.

\section{Pengaruh Lingkungan Kerja Fisik dan Non Fisik Terhadap Kepuasan Kerja}

Lingkungan kerja atau lokasi kerja dapat dikatakan segala sesuatu yang ada disekitar para pekerja dan yang dapat mempengaruhi dalam menjalankan tugas-tugas yang dibebankan. Lingkungan kerja adalah keseluruhan alat perkakas dan bahan yang dihadapi, lingkungan sekitarnya dimana seseorang bekerja, metode kerjanya, serta pengetahuan kerjanya baik sebagai perseorangan maupun sebagai kelompok (Sedarmayanti, 2011). Lingkungan kerja adalah segala sesuatu yang ada di lingkungan sekitar para pekerja dan yang dapat mempengaruhi dirinya dalam menjalankan tugas-tugas yang dibebankan kepadanya, misalnya kebersihan, musik, dan lain-lain (Nitisemito, 2009). Dari pendapat tersebut dapat disimpulkan bahwa lingkungan kerja adalah faktor-faktor fisik atau non fisik yang ada disekitar pekerjaan yang dapat mempengaruhi karyawan dalam menjalankan tugastugas yang dibebankan kepadanya.

Dalam lingkungan kerja fisik yang menyangkut tentang pewarnaan ruangan, disini arti dari pewarnaan sangatlah luas tidak hanya pewarnaan dinding tetapi seragam dan peralatan. Karyawan akan senang bekerja bila ruangan yang ditempati itu berwarna cerah, bersih dan serasi. Kebersihan lingkungan tempat untuk bekerja juga harus dijaga agar selalu bersih. Selain tempat yang bersih juga pengaturan suhu udara yang baik, agar sirkulasi udara yang ada di dalam kantor itu dapat berganti-ganti dan tidak pengap. Demikian juga dengan penerangan, ruang gerak, kebisingan, keamanan dan peralatan. Dengan kondisi ruang kerja yang demikian ini, maka karyawan akan merasa puaas dan senang karena pemimpin menghargai kerja mereka dengan menyediakan fasilitas yang memadai untuk bekerja. Hal ini juga dipengaruhi oleh lingkungan kerja non fisik, lingkungan ini menyangkut hubungan karyawan dengan karyawan, dan hubungan karyawan dengan pemimpin. Hubungan ini sangat penting untuk berlangsungnya kerja organisasi. Tanpa adanya hubungan ini maka karyawan tidak akan menemukan kepuasan dan kegiatan karyawan tidak dapat berjalan dengan apa yang menjadi tujuan dari perusahaan atau organisasi. Yulianti (2008) dalam penelitiannya mengemukakan bahwa lingkungan kerja fisik dan lingkungan kerja non fisik merupakan faktor yang dapat meningkatkan kepuasan kerja karyawan pada rumah sakit juanda kuningan.

H3: Terdapat pengaruh positif lingkungan kerja kerja fisik dan lingkungan kerja non fisik secara simultan terhadap kepuasan kerja karyawan. 


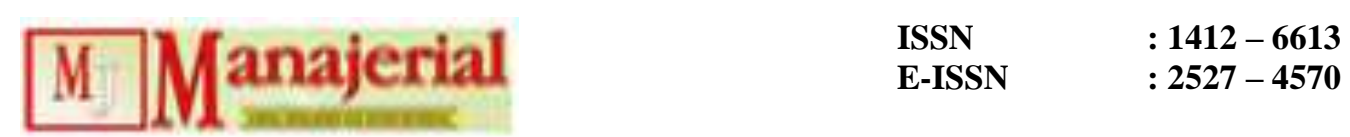

Gambar 1.1

Model Penelitian

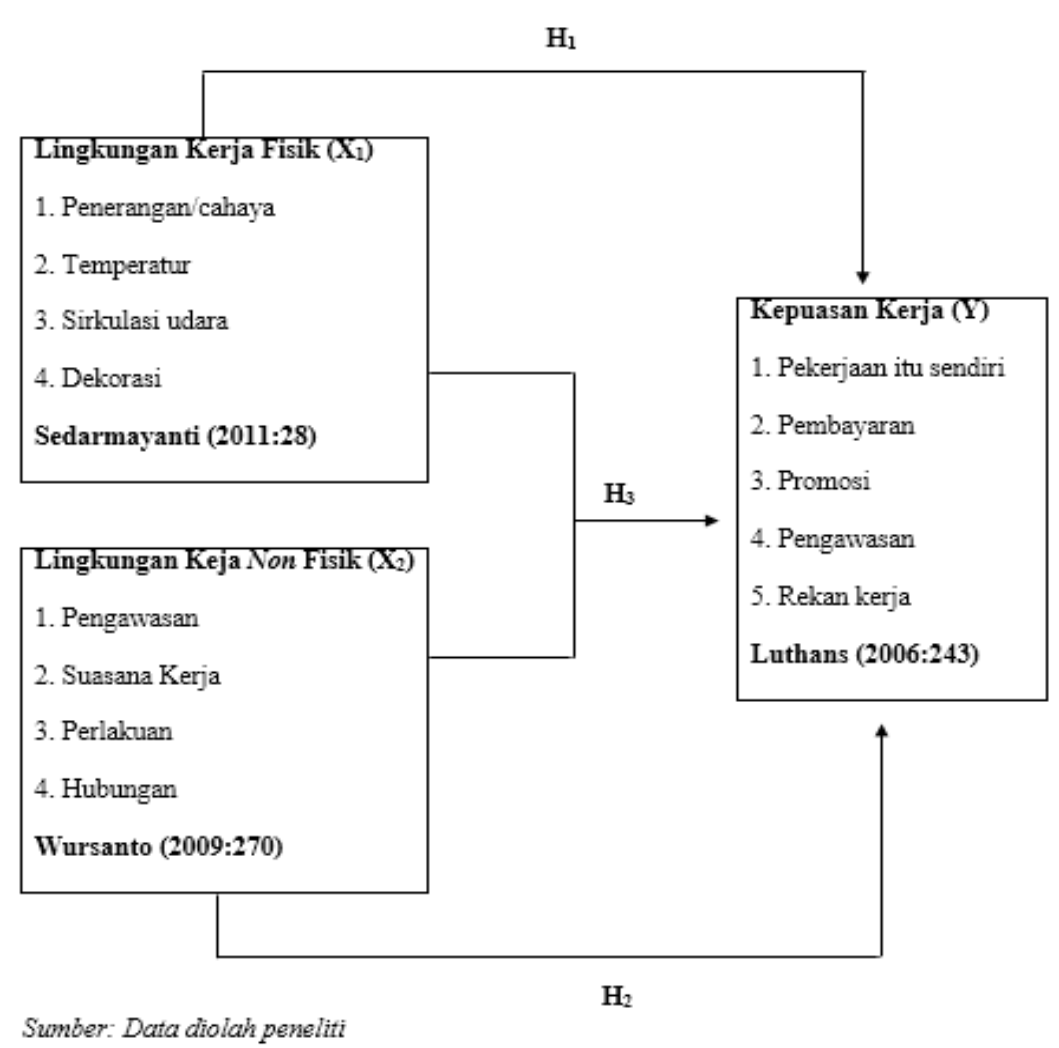

Penelitian

Gambar 1

Model

\section{METODOLOGI PENELITIAN}

Penelitian ini menggunakan jenis penelitian Deskriptif Asosiatif. Teknik pengumpulan data dengan menggunakan kuesioner. Sampel dalam penelitian ini sebanyak 63 orang karyawan kantor PT Nusa Konstruksi Enjiniring PLTM Cikaengan 2 Garut yang kemudian dijadikan populasi, teknik sampling yang digunakan dalam penelitian ini adalah teknik sampling sensus atau jenuh. Pengujian instrumen yang dipakai adalah uji validitas dan uji reliabilitas sedangkan jenis analisis yang dipakai adalah analisis regresi berganda.

\section{Ukuran Variabel}

Variabel lingkungan kerja fisik diukur dengan 12 item yang diadopsi dari Sedarmayanti (2011) dan lingkungan kerja non fisik diukur dengan 10 item yang diadopsi dari Dharmawan (2011), sementara variabel terikat pada penelitian ini yaitu kepuasan kerja karyawan diukur dengan 20 item yang diadopsi dari Luthans (2006).

\section{HASIL DAN PEMBAHASAN Uji Validitas dan Reliabilitas}

Pengujian validitas instrumen penelitian dilakukan pada 36 responden untuk mengukur validitas dalam penelitian ini dilakukan dengan menggunakan korelsi pearson (pearson moment coefficient or correlation). Sedangkan pengujian reliabilitas menggunakan Cronbach alpha. Berikut pengujian intrumen lingkungan kerja fisik $\left(\mathrm{X}_{1}\right)$, lingkungan kerja non fisik $\left(\mathrm{X}_{2}\right)$ dan kepuasan kerja $(\mathrm{Y})$. 
Tabel. 1

Hasil Uji Validitas Dan Reliabilitas

\begin{tabular}{|c|c|c|c|c|c|}
\hline No & Item & Lingkungan & & Kepuasan & Cronbach's \\
\hline & & $\begin{array}{l}\text { Kerja } \quad \text { Fisik } \\
\left(\mathrm{X}_{1}\right)\end{array}$ & $\begin{array}{l}\text { Kerja Non } \\
\text { Fisik }\left(\mathbf{X}_{2}\right)\end{array}$ & Kerja (Y) & \\
\hline 1 & $\begin{array}{l}\text { Penerangan } \\
\text { tempat kerja }\end{array}$ & $0,621 * *$ & & & \\
\hline 2 & Sumber cahaya & $0,683 * *$ & & & \\
\hline 3 & $\begin{array}{l}\text { Pendistribusian } \\
\text { cahaya }\end{array}$ & $0,602 * *$ & & & \\
\hline 4 & $\begin{array}{l}\text { Suhu panas di } \\
\text { tempat kerja }\end{array}$ & $0,621 * *$ & & & 0,758 \\
\hline 5 & $\begin{array}{l}\text { Suhu dingin di } \\
\text { tempat kerja }\end{array}$ & $0,683 * *$ & & & \\
\hline 6 & $\begin{array}{l}\text { Suhu sedang di } \\
\text { tempat kerja }\end{array}$ & $0,602 * *$ & & & \\
\hline 7 & $\begin{array}{l}\text { Pertukaran udara } \\
\text { di tempat kerja }\end{array}$ & $0,450 * *$ & & & \\
\hline 8 & $\begin{array}{l}\text { Kesejukan di } \\
\text { tempat kerja }\end{array}$ & $0,393 *$ & & & \\
\hline 9 & $\begin{array}{ll}\text { Ventilasi } & \text { di } \\
\text { tempat kerja }\end{array}$ & $0,459 * *$ & & & \\
\hline 10 & $\begin{array}{l}\text { Warna cat } \\
\text { dinding di tempat } \\
\text { kerja }\end{array}$ & $0,369 *$ & & & \\
\hline 11 & $\begin{array}{l}\text { Penyimpanan } \\
\text { meja dan kursi di } \\
\text { tempat kerja }\end{array}$ & $0,402 * *$ & & & \\
\hline 12 & $\begin{array}{l}\text { Kebersihan } \\
\text { tempat kerja }\end{array}$ & $0,621 * *$ & & & \\
\hline 13 & Penekanan tugas & & $0,893 * *$ & & \\
\hline 14 & $\begin{array}{l}\text { Pengawasan dari } \\
\text { atasan }\end{array}$ & & $0,600 * *$ & & \\
\hline 15 & Keakraban & & $0,600 * *$ & & \\
\hline 16 & Kerjasama & & $0,893 * *$ & & \\
\hline 17 & Tanggung jawab & & $0,341^{*}$ & & 0,900 \\
\hline 18 & Serius dan tekun & & $0,893 * *$ & & \\
\hline 19 & Adil & & $0,725 * *$ & & \\
\hline 20 & $\begin{array}{l}\text { Kepercayaan dari } \\
\text { atasan }\end{array}$ & & $0,705 * *$ & & \\
\hline 21 & $\begin{array}{l}\text { Hubungan } \\
\text { karyawan dengan } \\
\text { atasan }\end{array}$ & & $0,893 * *$ & & \\
\hline 22 & $\begin{array}{l}\text { Hubungan } \\
\text { karyawan denga } \\
\text { rekan kerja }\end{array}$ & & $0,705^{*}$ & & \\
\hline 23 & $\begin{array}{l}\text { Minat terhadap } \\
\text { pekerjaan }\end{array}$ & & & $0,717 * *$ & \\
\hline
\end{tabular}




\begin{tabular}{|c|c|c|c|}
\hline 24 & Rasa nyaman & $0,366^{*}$ & \multirow{19}{*}{0,913} \\
\hline 25 & $\begin{array}{l}\text { Mampu } \\
\text { menyelesaikan }\end{array}$ & $0,670 * *$ & \\
\hline 26 & Jumlah dan adil & $0,717 * *$ & \\
\hline 27 & $\begin{array}{l}\text { Waktu } \\
\text { pembayaran }\end{array}$ & $0,670 * *$ & \\
\hline 28 & Benefit & $0,734 * *$ & \\
\hline 29 & $\begin{array}{l}\text { Kesempatan } \\
\text { Untuk } \\
\text { Berkembang }\end{array}$ & $0,625 * *$ & \\
\hline 30 & Prestasi erja & $0,672 * *$ & \\
\hline 31 & Pengalaman & $0,375^{*}$ & \\
\hline 32 & $\begin{array}{l}\text { Tingkat } \\
\text { pendidikan }\end{array}$ & $0,384 *$ & \\
\hline 33 & Kejujuran & $0,734 * *$ & \\
\hline 34 & Tanggung jawab & $0,745 * *$ & \\
\hline 35 & $\begin{array}{l}\text { Berpusat pada } \\
\text { karyawan }\end{array}$ & $0,473 * *$ & \\
\hline 36 & $\begin{array}{l}\text { Partisipasi atau } \\
\text { pengaruh } \\
\text { pemimpin }\end{array}$ & $0,485 * *$ & \\
\hline 37 & Keakraban & $0,685 * *$ & \\
\hline 38 & Kepercayaan & $0,638 * *$ & \\
\hline 39 & Dukungan & $0,503 * *$ & \\
\hline 40 & Kenyamanan & $0,745 * *$ & \\
\hline 41 & Nasihat & $0,664 * *$ & \\
\hline 42 & Tim Kerja & $0,672 * *$ & \\
\hline
\end{tabular}

Sumber: Data diolah peneliti 2018

Dari tabel diatas menunjukan bahwa semua item pernyataan lingkungan kerja fisik, lingkungan kerja non fisik dan lepuasan kerja semuanya valid, hal ini dibuktikan dengan nilai korelasi atau $\mathrm{R}$ hitung lebih besar dari 0,30. Maka dari itu, item pernyataan koesioner tersebut dapat dijadikan alat ukur variabel yang diteliti. Sedangkan nilai cronbach's alpha lingkungan kerja fisik sebesar 0,758, lingkungan kerja non fisik sebesar 0,900 dan kepuasan kerja sebesar 0,913. dengan demikian, instrumen penelitian ini reliabel untuk digunakan sebagai alat ukur suatu instrumen penelitian karena lebih dari 0.60 .

\section{Analisis Regresi Linier Berganda}

Pada bagian ini akan diuji pengaruh lingkungan kerja fisik dan lingkungan kerja non fisik terhadap kepuasan kerja karyawan menggunakan regresi linier berganda dengan persamaan sebagai berikut: 


\begin{tabular}{|lll}
\hline & ISSN & $: 1412-6613$ \\
& & $: 2527-4570$
\end{tabular}

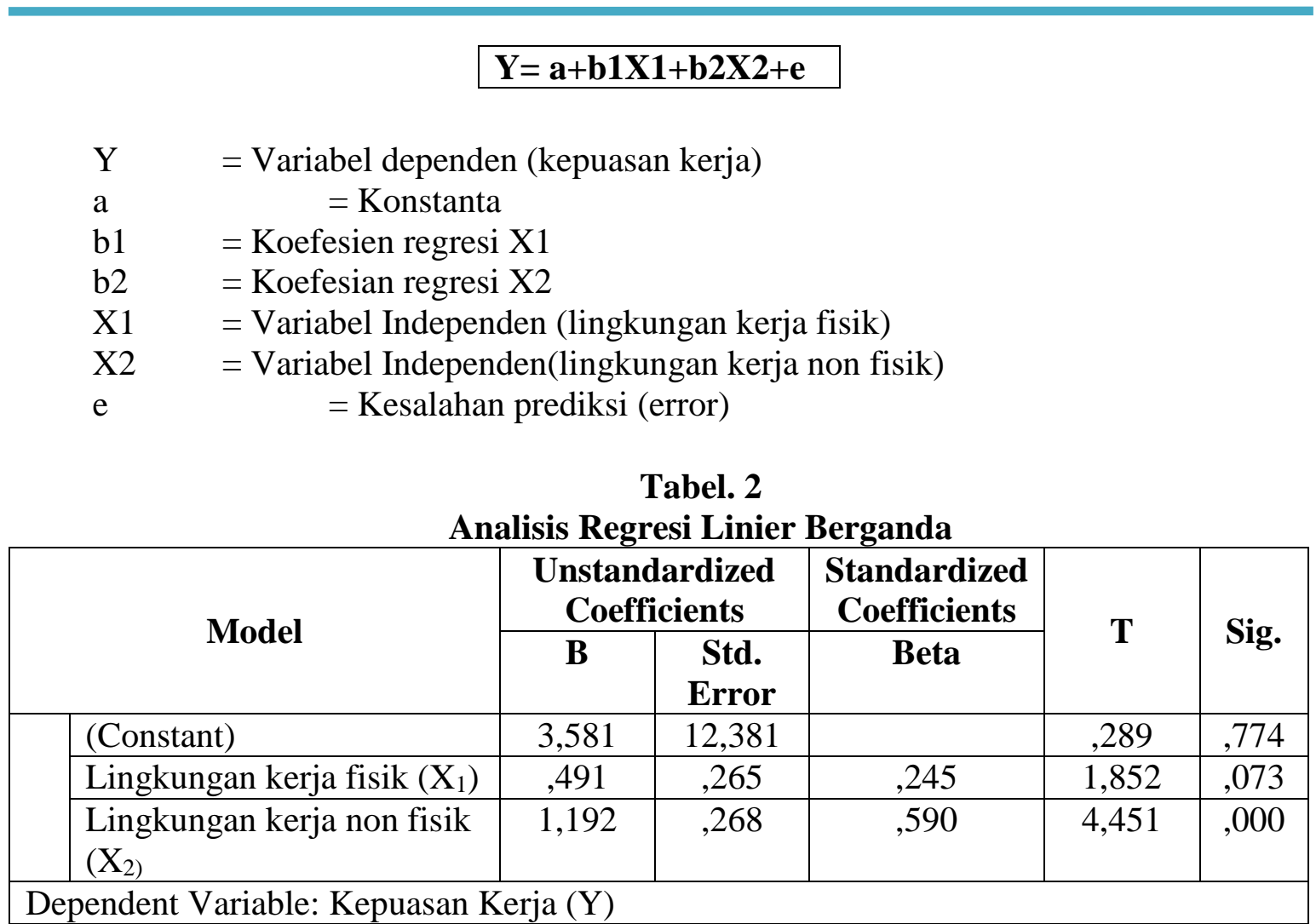

Sumber: Data diolah peneliti

Berdasarkan tabel di atas, diperoleh nilai a sebesar 3,581 nilai b1 sebesar 0,491 nilai b2 sebesar 1,192 dengan demikian maka dapat dibentuk persamaan regresi linier berganda dalam penelitian ini adalah sebagai berikut:

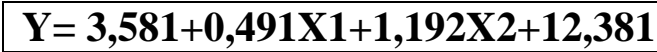

Nilai koefesien regresi pada variabel-variabel independen menggambarkan apabila diperkirakan jika variabel independen naik satu maka diperkirakan variabel independen lainnya konstan atau sama dengan tanda koefisien regresi variabel independennya. Persamaan di atas dapat diinterprestasikan sebagai berikut:

a. Konstanta sebesar 3,581 menyatakan bahwa jika lingkungan kerja fisik $\left(\mathrm{X}_{1}\right)$ dan lingkungan kerja non fisik $\left(\mathrm{X}_{2}\right) 0$ maka nilai kepuasan kerja $(\mathrm{Y})$ adalah 3,582.

b. Tanda koefesien regresi variabel independen lingkungan kerja fisik $\left(\mathrm{X}_{1}\right)$ menunjukan arah positif sebesar 0,491. Jika lingkungan kerja fisik meningkat sebesar satu kali maka akan diikuti dengan kenaikan kepuasan kerja (Y) sebesar 0,491.

c. Tanda koefesien regresi variabel independen lingkungan kerja non fisik $\left(\mathrm{X}_{2}\right)$ menunjukan arah positif sebesar 1,192. Jika lingkungan kerja non fisik meningkat sebesar satu kali maka akan diikuti dengan kenaikan kepuasan kerja (Y) sebesar 1,192.

\section{Hasil Uji Parsial (t)}

a. Pengujian hipotesis lingkungan kerja fisik $\left(\mathrm{X}_{1}\right)$ berpengaruh positif terhadap kepuasan kerja (Y).

Variabel lingkungan kerja fisik tidak berpengaruh signifikan terhadap kepuasan kerja, hal ini terlihat dari nilai signifikan 0,073 lebih besar dari 0,05 dan nilai thitung sebesar 1,852 
lebih kecil dari $t_{\text {tabel }}$ yaitu 2,035. Hal ini menunjukan bahwa $\mathrm{H}_{0}$ diterima artinya lingkungan kerja fisik $\left(\mathrm{X}_{1}\right)$ tidak tidak berpengaruh terhadap kepuasan kerja (Y).

b. Pengujian hipotesis lingkungan kerja non fisik $\left(\mathrm{X}_{2}\right)$ berpengaruh positif terhadap kepuasan kerja (Y).

Variabel lingkungan kerja non fisik berpengaruh positif dan signifikan terhadap kepuasan kerja, hal ini dilihat dari nilai signifikan 0,000 lebih kecil dari 0,05 dan nilai thitung sebesar 4,451 lebih besar dari tabel yaitu 2,035. Hal ini menunjukan bahwa $\mathrm{H}_{0}$ ditolak artinya lingkungan kerja non fisik $\left(\mathrm{X}_{2}\right)$ berpengaruh signifikan dan positif terhadap kepuasan $\operatorname{kerja}(\mathrm{Y})$.

\section{Hasil Uji Simultan (F)}

Uji simultan atau uji $\mathrm{F}$ ini digunakan untuk mengetahui pengaruh semua variabel independen yaitu lingkungan kerja fisik $\left(\mathrm{X}_{1}\right)$ dan lingkungan kerja non fisik $\left(\mathrm{X}_{2}\right)$ secara bersama-sama terhadap variabel dipenden yaitu kepuasan kerja (Y) dengan melihat nilai signifikansinya, dimana dikatakan signifikan jika nilai signifikansinya lebih kecil dari 0,05 dan membandingkan antara nilai $\mathrm{F}$ hitung dengan $\mathrm{F}$ tabel dimana dikatakan signifikan jika F hitung lebih besar dari F tabel.

Tabel. 3

Hasil Output Uji F

\begin{tabular}{|l|l|c|c|c|c|c|}
\hline \multicolumn{2}{|l|}{ Model } & Sum of Squares & Df & Mean Square & F & Sig. \\
\hline & Regression & 1813,935 & 2 & 906,967 & 19,323 &, $000^{\mathrm{b}}$ \\
\cline { 2 - 7 } & Residual & 1548,954 & 33 & 46,938 & & \\
\cline { 2 - 6 } & Total & 3362,889 & 35 & & & \\
\hline \\
a. Dependent Variable: Kepuasan Kerja (Y) \\
b. Predictors: (Constant), Lingkungan kerja Fisik $\left(\mathrm{X}_{1}\right)$, lingkungan kerja non fisik $\left(\mathrm{X}_{2}\right)$ \\
\hline
\end{tabular}
Sumber: Data diolah peneliti

Berdasarkan tabel diatas, terlihat bahwa nilai signifikansinya sebesar 0,000 lebih kecil dari 0,05 dan nilai $F$ hitung sebesar 19,323 lebih besar dari $F$ tabel yaitu 3,32. Hal ini menunjukan bahwa $\mathrm{H}_{0}$ ditolak, artinya lingkungan kerja fisik $\left(\mathrm{X}_{1}\right)$ dan lingkungan kerja non fisik $\left(\mathrm{X}_{2}\right)$ secara simultan (bersama-sama) berpengaruh positif dan signifikan terhadap kepuasan kerja (Y).

\section{Hasil Uji Koefesien Determinasi $\left(\mathbf{R}^{2}\right)$}

Koefesien determinasi $\left(\mathrm{R}^{2}\right)$ pada initinya mengukur seberapa jauh dan seberapa besar kemampuan model dalam menerangkan variasi variabel dependen.

Tabel. 4

Koefesien Determinasi

\begin{tabular}{|c|c|c|c|c|}
\hline Model & R & R Square & Adjusted R Square & Std. Error of the Estimate \\
\hline 1 &, $734^{\mathrm{a}}$ &, 539 &, 511 & 6,85113 \\
\hline
\end{tabular}

Sumber: Data diolah peneliti

Berdasarkan tabel diatas dapat diketahui bahwa makna nilai $\mathrm{R}$ square sebesar 0,539 artinya bahwa kepuasank kerja karyawan kantor PT Nusa Konstruksi Enjiniring PLTM 
Cikaengan 2 Garut dipengaruhi oleh lingkungan kerja fisik dan lingkungan kerja non fisik sebesar $53,9 \%$ dan sisanya $46,1 \%$ dipengaruhi oleh faktor-faktor lain yang tidak diteliti.

\section{PEMBAHASAN}

\section{Pengaruh Lingkungan Kerja Fisik ( $\left.\mathrm{X}_{1}\right)$ Terhadap Kepuasan Kerja Karyawan (Y)}

Berdasarkan hasil analisis regresi linier berganda diketahui bahwa variabel independen lingkungan kerja fisik $\left(\mathrm{X}_{1}\right)$ berpengaruh terhadap kepuasan kerja karyawan $(\mathrm{Y})$, hal ini dapat dilihat dari nilai signifikan 0,073>0,05 dan nilai thitung sebesar 1,852 lebih kecil dari tabel yaitu 2,035. Berdasarkan temuan di atas, menunjukan bahwa lingkungan kerja fisik tidak mempunyai pengaruh yang signifikan terhadap kepuasan kerja. Artinya, tingkat signifikansi tidak memiliki makna bahwa lingkungan kerja fisik memiliki peranan penting untuk meningkatkan kepuasan kerja.

Hasil penelitian ini diperkuat oleh teori atribusi (Attribution Theory) yang menjelaskan tentang prilaku seseorang. Teori ini mengargumentasikan bahwa prilaku seseorang itu ditentukan oleh kombinasi antara kekuatan internal (internal forces) yaitu faktor-faktor yang berasal dari dalam diri seseorang (individu) misalnya kemampuan, pengetahuan atau usaha; sedangkan kekuatan eksternal (eksternal forces) yaitu faktor-faktor yang berasal dari luar, misalnya keberuntungan, kesempatan dan lingkungan (Fritz Heider, 1958 dalam Hudayanti, 2002). Hasil penelitian ini dititik beratkan pada (internal forces) dimana seseorang akan berprilaku tertentu sesuai dengan sikap dan niat yang ada pada dirinya masing-masing. Berkaitan dengan hasil penelitian ini lingkungan kerja fisik tidak berpengaruh terhadap kepuasan kerja karena individu-individu ataupun karyawan sudah merasa terbiasa dengan lingkungan kerja fisik tersebut. Selain itu, hasil penelitian ini juga didukung oleh teori dua faktor (two factor theory) yang dikemukakan oleh seorang psikolog yang bernama Frederick Herzberg. Dua faktor yang dapat menyebabkan timbulnya rasa puas atau tidak puas menurut Herzberg, yaitu faktor pemeliharaan (hygiene factors) dan faktor motivasi (motivator factors) karena kondisi itu diperlukan untuk memelihara kepuasan yang layak menurut Herzberg dalam Hasibuan (2006). Hasil penelitian ini sangat erat kaitannya dengan faktor pemeliharaan (hygiene factors) atau ektrinsik pekerjaan yang dimana salah satu faktornya adalah kondisi kerja (working conditions). Secara ringkas, dinyatakan oleh Herzberg, bahwa faktor pemeliharaan hygiene factors atau faktor pemeliharaan menyebabkan banyak ketidakpuasan bila faktor tersebut tidak ada, tetapi memberi motivasi jika faktor itu ada. Sebaliknya motivator membimbing kearah motivasi yang kuat dan pemuasan bila faktor itu ada, tetapi tidak menyebabkan ketidakpuasan jika faktor tersebut tidak ada. Hasil penelitian ini juga didukung dengan hasil penelitian Gilang dan Cintia (2016) yang mengemukakan bahwa berdasarkan hasil analisis regresi linier berganda menunjukan bahwa secara parsial lingkungan kerja fisik mempunyai pengaruh yang signifikan terhadap kepuasan kerja karyawan.

\section{Pengaruh Lingkungan Kerja Non Fisik $\left(\mathrm{X}_{2}\right)$ Terhadap Kepuasan Kerja Karyawan (Y)}

Berdasarkan hasil analisis regresi linier berganda diketahui bahwa variabel lingkungan kerja non fisik memiliki nilai koefesien regresi sebesar 1,192 artinya bahwa variabel lingkungan kerja fisik berpengaruh positif atau berbanding lurus terhadap kepuasan kerja karyawan. Artinya adalah semakin baik lingkungan kerja non fisik, maka kepuasan kerja akan semakin meningkat. Hasil uji $t$ terdapat bahwa variabel independen lingkungan kerja fisik $\left(\mathrm{X}_{2}\right)$ memiliki pengaruh yang signifikan terhadap kepuasan kerja karyawan (Y), hal ini dapat dilihat dari nilai signifikan $0,000<0,05$ dan nilai thitung sebesar 4,451 lebih besar dari $t_{\text {tabel }}$ yaitu 2,035. 
Hasil penelitian ini juga diperkuat oleh teori atribusi (attribution theory), namun dalam hasil penelitian ini lebih di titikberatkan pada kekuatan eksternal (eksternal force) dimana seseorang akan berprilaku tertentu jika ada dorongan dari luar yang mempengaruhinya salah satunya adalah lingkungan. Seperti halnya dalam hasil penelitian ini yang dimana lingkungan kerja non fisik yang didalamnya terdapat hubungan-hubungan dengan orang lain baik atasan maupun rekan kerja, perlakuan, keakraban dan lain-lain mempengaruhi prilaku karyawan atau kepuasan kerja. Artinya baik atau tidaknya lingkungan (lingkungan kerja non fisik) maka akan menyebabkan atau mempengaruhi prilaku (kepuasan kerja) seseorang atau karyawan tersebut. Selain itu, hasil penelitian ini juga sejalan dengan pendapat Sedarmayanti (2011) yang menyatakan bahwa lingkungan kerja non fisik adalah semua keadaan yang terjadi yang berkaitan dengan hubungan kerja, baik hubungan dengan atasan maupun hubungan sesama rekan kerja, ataupun hubungan dengan bawahan.

Berdasarkan temuan di atas, menunjukan bahwa lingkungan kerja non fisik mempunyai pengaruh yang signifikan terhadap kepuasan kerja. Artinya bahwa lingkungan kerja non fisik berperan penting untuk meningkatkan kepuasan kerja karyawan. Hal ini terjadi karena lingkungan kerja non fisik seperti pengawasan, suasana kerja, perlakuan dan hubungan semakin baik, maka kepuasan kerja karyawanpun akan semakin baik. Hasil penelitian ini didukung dengan hasil penelitian yang dilakukan oleh Sarah dan Utami (2016) yang mengemukakan bahwa semakin baik lingkungan kerja non fisik, maka akan menciftakan suatu pekerjaan yang menyenangkan untuk dikerjakan, sehingga akan menimbulkan rasa kepuasan kerja pada karyawan.

\section{Pengaruh Lingkungan Kerja Fisik $\left(\mathrm{X}_{1}\right)$ dan Lingkungan Kerja Non Fisik $\left(\mathrm{X}_{2}\right)$ terhadap Kepuasan Kerja Karyawan (Y)}

Variabel independen dalam penelitian ini adalah lingkungan kerja fisik dan lingkungan kerja non fisik. Berdasarkan hasil pengujian simultan atau uji $\mathrm{F}$ di atas menunjukan bahwa secara simultan lingkungan kerja fisik dan lingkungan kerja non fisik berpengaruh secara simultan (bersama-sama) terhadap kepuasan kerja karyawan.

Hasil temuan ini sejalan dengan pendapat yang dikemukakan oleh Robbins (1996), menyatakan bahwa sebagian besar karyawan lebih menyukai bekerja dalam fasilitas yang bersih dan relatif modern dan didukung dengan peralatan yang memadai. Begitu juga dengan pendapat yang dikemukakan oleh Nitisemito (2009) lingkungan kerja adalah segala sesuatu yang ada dilingkungan sekitar para pekerja dan yang dapat mempengaruhi dirinya dalam menjalankan tugas-tugas yang dibebankan kepadanya misalnya kebersihan, musik, dan lainlain.

Berdasarkan hasil penelitian ini dapat disimpulkan bahwa jika lingkungan kerja pada PT Nusa Konstruksi Enjiniring PLTM cikaengan 2 Garut semakin baik, maka kepuasan kerja akan semakin meningkat pula. Kondisi lingkungan yang dimaksud tidak hanya terbatas pada kenyamanan fisik yang dapat dinikmati seara langsung, namun juga lingkungan non fisik yang dapat dirasakan oleh seluruh karyawan karena lingkungan kerja non fisik yang kondusif dapat membuat karyawan merasa nyaman dan betah bekerja di perusahaan sehingga bisa meningkatkan kepuasan kerja karyawan. Hasil penelitian ini didukung dengan hasil penelitian yang dilakukan oleh Himawan (2014) dalam penelitiannya yang mengemukakan bahwa lingkungan kerja yang dirasakan oleh karyawan berdampak terhadap kepuasan kerjanya, dengan kata lain kepuasan kerjanya akan tinggi. 


\section{KESIMPULAN}

Penelitian tentang lingkungan kerja tidak selalu berpengaruh pada kepuasan kerja terlihat dari hasil penelitian ini bahwa lingkungan kerja fisik tidak berpengaruh terhadap kepuasan kerja. Artinya, hal ini menunjukan bahwa baik atau tidaknya ligkungan kerja fisik tidak terlalu mempengaruhi dan tidak berdampak terhadap kepuasan kerja karyawan. Sedangkan lingkungan kerja non fisik berpengaruh positif terhadap kepuasan kerja. Artinya, semakin tinggi lingkungan kerja non fisik yang meliputi pengawasan, suasana kerja, perlakuan dan hubungan maka semakin tinggi pula kepuasan kerja karyawan. Namun secara bersama-sama lingkungan kerja fisik dan lingkungan kerja non fisik berpengaruh positif terhadap kepuasan kerja karyawan. Artinya, semakin tinggi lingkungan kerja fisik dan lingkungan kerja non fisik secara bersama-sama maka semakin tinggi pula kepuasan kerja karyawan.

Pengembangan penelitian harus dilakukan untuk membangun suatu penelitian yang maju. Oleh sebab itu penelitian ini hanya terfokus pada dua variabel independen yaitu lingkungan kerja fisik dan lingkungan kerja non fisik, sedangkan masih banyak faktor-faktor lain yang mempengaruhi kepuasan kerja karyawan. Selan itu, penelitian ini hanya mengetahui pengaruh langsung antara lingkungan kerja fisik dan lingkungan kerja non fisik terhadap kepuasan kerja karyawan tanpa meneliti variabel moderasi atau variabel mediasi. Hal lain yang perlu dipertimbangkan adalah perusahaan yang dijadikan objek hanya sebagian kecil dari keseluruhan perusahaan yang hanya memiliki 36 pegawai.

\section{DAFTAR PUSTAKA}

Agbozo. George Kafui, Owusu. Isaac Sakyi , Hoedoafia. Mabel A, dan Atakorah. Yaw Boateng. 2017. The Effect of Work Environment on Job Satisfaction: Evidence from the Banking Sector in Ghana. Journal of Human Resource Management: Volume 5, Issue 1, February 2017, Pages: 12-18

Bakotic, D., \& Babic, T. B. (2013, February). Relationship between Working Conditions and Job Satisfaction: The Case of Croatian Shipbuilding Company. International Journal of Business and Social Science, 4(2), 206-213.

Chandrasekar, K. (2011, January). Workplace Environment and Its Impact Organizational Performance in Public Sector organizations. International Journal of Enterprise Computing and Business Systems, 1(1), 1-19

Dawal Siti Zawiah Md and Zahari Taha. 2006. The Effect Of Job and Environmental Factors on Job Satifaction in Automotive Industries. Internastional Journal of Occupational safety and economics (JOSE) Vol. 12, NO. 3, 267-280. University of Malaya. Malaysia

Dharmawan, Yusa. 2011. Pengaruh Kompensasi dan Lingkungan Kerja Non Fisik terhadap Disiplin dan Kinerja Karyawan Hotel Nikki Denpasar. Tesis Universitas Udayana. Denpasar

Fath Alam Robby. 2015. Pengaruh Lingkungan Kerja Non Fisik dan Karakteristik Pekerjaan Terhadap Kepuasan Kerja (Studi Pada Karyawan Hotel Bintang dua di Yogyakarta). Skripsi Fakultas Ekonomi Universitas Negeri Yogyakarta

Gilang, Ailini dan Cintia Eldaa. 2016. Pengaruh Lingkungan Kerja Fisik dan Non Fisik Terhadap Kinerja Karwayan Pada KPPN Bandung 1. Jurnal Sosioteknologi Vol. 15, No

1. Universitas Telkom, Bandung

Himawan, Hadinata. 2014. Pengaruh lingkungan Kerja dan Jompensasi Terhadap Kepuasan Kerja Karyawan Pabrik Genteng Massoka Kebumen, Jawa Tengah Skripsi Fakultas Ekonomi Universitas Negeri Yogyakarta 


\begin{tabular}{|lll}
\hline$M$ & ISSN & $: 1412-6613$ \\
& E-ISSN & $: 2527-4570$
\end{tabular}

Hasibuan, Malayu. S.P. 2006. Organisasi dan Motivasi (Dasar Peningkatan Produktivitas). Jakarta: Bumi Aksara

Hasibuan, Malayu. S.P. 2003. Manajemen Sumber Daya Manusia. Bandung: Bumi Askara

Hendri, Edduar. 2012. Pengaruh Lingkungan Kerja Fisik Dan Non Fisik Terhadap Kepuasan Kerja Karyawan Pada PT Asuransi Wahana Tata Cabang Palembang. Jurnal Wahana Ekonomika Vol 9 No. 3

Hudayanti Ataina. 2002. Perkembangan Penelitian Akuntasi Keperilakuan: Berbagai Teori dan Pendekatan yang Melandasi. JAAI Volume 6 No. 2. Universitas Islam Indonesia. Yogyakarta

Luthans, Fred. 2006. Prilaku Organisasi: edisi 10. Alih bahasa Vivin Andika Yurwono dkk. Yogyakarta: Andi

Nitisemito A. 2009. Manajemen Personalia: Edisi Kedua. Jakarta: Gahlia Indonesia

Robbins P. Stephent. 1996. Perilaku Organisasi Edisi Bahasa Indonesia. Jakarta: Prenhallindo

Raziq, Abdul dan Maulabakhsh, Raheela. 2014. Impact of Working Environment on Job Satisfaction. Procedia Economics and Finance. Vol: 23717 - 725

Sarah, Sunuharyo dan Utami. 2016. Pengaruh Lingkungan Kerja Fisik dan Non Fisik Terhadap Kepuasan Kerja dan Kinerja Karyawan (Studi Pada Karyawan PT Telkom Indonesia Witel Jatim Selatan Malang). Jurnal Administrasi Bisnis. (JAB). Vol. 40. No. 1. Universitas Brawijaya, Malang

Sedarmayanti. 2011. Manajemen Sumber Daya Manusia, Reformaasi Birokrasi dan Manajemen Pegawai Negri Sipil. Bandung: Refika Aditama

Wursanto, Ignasius. 2009. Dasar-dasar Ilmu Organisasi: Edisi kedua. Yogyakarta: Andi

Yulianti Eli. 2008. Pengaruh lingkungan Kerja Terhadap Kepuasan Kerja Karyawan (Studi Rumah Sakit Juanda Kuningan). Skripsi Fakultas Keguruan dan Ilmu Pendidikan, Universitas Shanata Darma Yogyakarta 